\title{
ORGANIZATIONAL CLIMATE AND ADMINISTRATIVE PERFORMANCE'S CONTRIBUTION TOWARD ACADEMIC SERVICE SATISFACTION IN VOCATIONAL SCHOOL (A STUDY ON PUBLIC VOCATIONAL SCHOOLS IN PALANGKARAYA)
}

\author{
Asti Putri Kartiwi ${ }^{\text {a* }}$ \\ ${ }^{a *}$ Universitas Muhammadiyah Sukabumi \\ Jl. R. Syamsudin, S.H. No. 50, Sukabumi, Indonesia astiputri414@ummi.ac.id
}

\begin{abstract}
The core of the study was focused on the factors which affect service satisfaction, it includes the organizational climate and administrative performance. Based on this matter, the main problem revealed in this research was the measurement of organization climate and school administration performance's contribution toward the satisfaction of academic service. The results showed: (1) organizational climate, was in the already good category. (2) Administrative performance, was in the high category. (3) The satisfaction of academic service, was in high enough category. (4) The results of relationship analysis showed that both variables have a positive and significant relationship. Recommendations given to schools was to improve the quality of school administration in relation to the quality assurance of academic services at public vocational schools in Palangkaraya.
\end{abstract}

Keywords: Academic Service Satisfaction, Administrative Performance,Organization Climate, State Vocational School.

\section{INTRODUCTION}

The quality of education especially in schools is greatly influenced by a variety of factors including: Community culture, socioeconomic society, demographic government policy, educational administration funding, and management professionalism [1], [2], [3], [4].

As a system, the school also consists of several interrelated components and interplay between one another [5], [6], [7].

The problem is, how should schools be structured in order to be able to create the quality of service that they want? Carrying capacity and contextual issues aspects are most likely influence the configuration of school organizational structures which meet the achieving quality criteria. The quality of a school can also be viewed from the administrative orderliness [8], [9].

The performance of school administrators is realized (consciously or not) as one of the factors affecting the quality of a school [10], [11], [12], [13], [14].

The society paradigm which insists on sending a child to a college degree is not completely wrong, but it must be adjusted to the child's talent and ability. Unfortunately, up to now most existing schools are categorized as high schools, not vocational schools which leads to the working area. If a child is educated in high school, then to enter the working area, he must attend for at least three more years or at the academy level. So to get into the working area, at least they are required to be a graduate 
academy. Or it could be longer if you want to reach full undergraduate program.

The condition was different in a case where students went directly to the vocational school, they will be able to enter the work place immediately after completing their study. At most will undergo a period of training for several months, then the students can enter the employment field in accordance with the chosen vocational. Vocational High School will be a school that produces a competent workforce in its field.

Central Kalimantan Province is a developing province. The development in all sectors, especially in the education, is being encouraged in such a way. The lack of interest of the community, especially the parents to educate their children in Vocational High School is one of the social obstacles that ought to be handled by the local government.

Figure 1

Graph of Junior High School Graduates Continuing to Higher Levels in 2007-2008

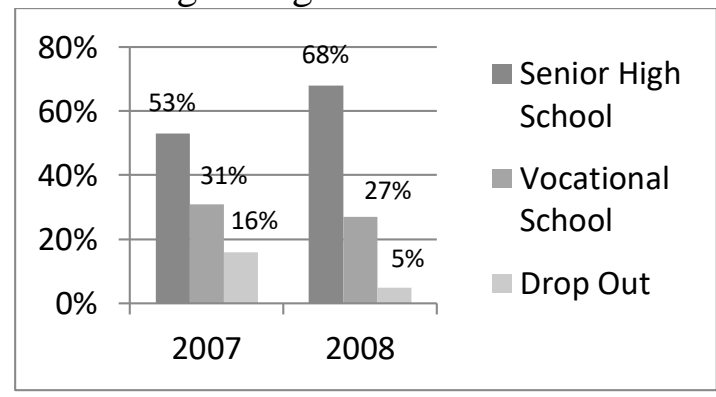

Source: Education Office of Central Kalimantan Province February 2009

From the graph above, it is identified that the junior high school graduates level of interest to continue to vocational school is still low compared to high school. Therefore, the improvement of Vocational High School quality needs to continuesly done by the local government. In addition, local government schools also required to continue in improving their quality by developing a better school management. Improving the quality of an institution ought to start from all small sectors as a part of the organization.

Quality improvement of Vocational High School covers all aspects of personnel and organizational management performance with the intention of knowing whether there is a relationship between organizational climate and school administration's performance on the satisfaction of academic administration services in vocational high schools. Thus, it is de rigueur to conduct in-depth research on the subject.

\section{METHODS}

The method used in this research is descriptive correlative with quantitative approach.

The design of correlational research states the degree of relationship between the variables investigated. In other words, the correlation is to state the relationship between one variable with another variable. So the descriptive correlative method will explain/describe the condition of each variable then connect it with other variables. Research design conducted in this study is using a comparative method, which compares one object of research with another.

The population of this study are students at $1 \mathrm{st}$ and 2nd Public Vocational School of Palangkaraya (SMK Negeri 1 and SMK Negeri 2 Palangkaraya) with the assumption that both schools are the oldest Public Vocational Schools in Central Kalimantan Province and owned ISO 2000. The number of sample are 171 students. 86 students are from SMKN 1 and 85 from SMKN 2.

\section{RESULTS AND DISCUSSION}

The theory in quantitative research is positioned as a tool for developing instruments and conducting analysis to study the phenomena occurring in the field. Below are the result of the research:

In the partial test rejection and acceptance, Ho is based on the value of $t$ test and the value of significance. If tcount $>$ ttable (1.654) then Ho is rejected and $\mathrm{Ha}$ accepted, or if significance value $<0,05$ then $\mathrm{Ho}$ is rejected and $\mathrm{Ha}$ accepted. In the simultaneous testing of rejection and acceptance of $\mathrm{Ho}$ is based on the $F$ test value and significance value. If the value Fcount> Ftable (3.049) then Ho is rejected and 
Ha accepted, or if the significance value $<0.05$ then Ho is rejected and Ha accepted.

To tranquil in observing school comparison with the implementation of ISO 9001: 2000 system with those schools which have not implemented the system, then this analysis is done per school.

Before conducting hypothesis testing, the researcher firstly look at the relationship between organizational climate and administrative performance. From the correlation analysis result, it was found a strong relationship between organizational climate and administrative performance at SMK Negeri 1 Palangkaraya with the score of 0.752 . It means that the two variables are alongside in a positive way. While at SMK Negeri 2 Palangkaraya the relationship between variable $\mathrm{X} 1$ (organizational climate) with X2 (administrative performance) is very weak $(0,051)$, meaning that unconvincing relation make the two variables are alongside but have very small influence between one variable with another.

The result of relationship between $\mathrm{X} 1$ (organizational climate) and Y (academic service satisfaction) analysis at SMK Negeri 1 shows 0,757 score, denoting if there is 1 addition of organizational climate hence academic service satisfaction will increase equal to 0,757 or $75,7 \%$. Significant 0.000 or probability below 0.05 indicates that $\mathrm{Ho}$ is rejected. It can be intepreted that organizational climate has an influence on the academic services satisfaction. Meanwhile, the relationship of X2 (organizational climate) and $\mathrm{Y}$ (academic service satisfaction) at SMK Negeri 2 shows the number 0,564 , denoting if there is 1 addition of organizational climate at SMK Negeri 2 then academic service satisfaction at SMK Negeri 2 will increase equal to 0,564 or $54,4 \%$. The influence of organizational climate on the academic services satisfaction at SMK Negeri 1 is viewed higher in comparison to SMK Negeri 2.

The result of the relationship analysis between X2 (administrative performance) and $\mathrm{Y}$ (academic services satisfaction) at SMK Negeri 1 shows the number 0,594 meaning if there is 1 addition of organizational climate then academic service satisfaction will increase equal to 0,594 or $59,4 \%$. Significant 0.000 or probability below 0.05 indicates that $\mathrm{Ho}$ is rejected. It can be intepreted that the administration's performance has an effect on the academic services satisfaction. Meanwhile, the relationship of $\mathrm{X} 2$ (administrative performance) and $\mathrm{Y}$ (academic service satisfaction) at SMK Negeri 2 shows the number 0,565 , denoting if there is 1 addition of administrative performance at SMK Negeri 2 then the satisfaction of academic service at SMK Negeri 2 will increase by 0,565 or $56,5 \%$. The influence of administrative performance on the academic services satisfaction at SMK Negeri 1 is viewed higher in comparison to SMK Negeri 2.

The result of relationship analysis between X1 (organizational climate) and X2 (administrative performance) collectively to $\mathrm{Y}$ (academic service satisfaction) at SMK Negeri 1 shows the numberof 0,295 (X1) and 0,330 (X2) denoting if there is 1 addition of organizational climate hence academic service satisfaction will increase equal to 0.295 or $29.5 \%$. And if the administrative performance is increased 1 addition, then the academic service satisfaction will increase by 0.330 or $33 \%$, significant with 0,000 or probability below 0.05 indicates that Ho is rejected. It can be intepreted that organizational climate and administrative performance really have a significant influence on the academic services satisfaction at SMK Negeri 1.

Meanwhile, the result analysis of the relationship between X1 (organizational climate) and X2 (administrative performance) simultaneously on $\mathrm{Y}$ (academic service satisfaction) at SMK Negeri 2 shows the numbers 0,596 (X1) and 0,591 (X2) denoting that if there is addition of organizational climate then academic service satisfaction will be increased by 0.594 or $59.4 \%$. And if the administrative performance is increased, then the academic service satisfaction will increase by 0,591 or $59,1 \%$, significant with 0,000 or probability below 0,05 indicates that $\mathrm{Ho}$ is rejected. It can be intepreted that organizational climate and administrative performance really 
have a significant influence on the academic services satisfaction at SMK Negeri 2.

Based on the results analysis, it was found that the relationship of organizational climate and administrative performance to the academic services satisfaction at SMK Negeri 2 is higher than the SMK Negeri 1, it is due to the fact that SMK Negeri 1 has not been applying quality standards for school services and governance performance. Note that effort is one of the factors which affect student satisfaction on academic services provided by vocational high schools in Palangkaraya.

In line with the opinion of [15] whom stated that the quality performance and tangible service quality will emerge if fulfilled by the following four conditions:

1. Quality awareness and orientation in all activities throughout the program, every process and product.

2. The program should have a strong humanitarian nature to bring quality to the way employees are treated and included, and inspired.

3. This program should be based on a decentralized approach that empowers all levels.

4. Total Quality Management (TQM) should be applied thoroughly so that all policy principles and habits reach every corner and gap of the organization.

In general, from the results of the study, it is revealed that administrative performance variable has greater influence on the academic services satisfaction than organizational climate variable. It is because indicators in the administration performances that includes professional skills, personal abilities, and social skills directly affect to the perceived of consumer education satisfaction; in this case, specifically refer to the student. Administration as a workforce that is directly related to consumer education is a central factor in improving the academic services satisfaction.

There is a big influence (shown in the data of SMK Negeri $156.4 \%$ and SMK Negeri 2 $60.7 \%$ ) from organizational climate variable and administrative performance provides a description that the school as a social institution which provides services, in an effort to improve the quality, must consider several aspects of the organization. Some of which are the quality of human resources, especially the school administration and maintaining the school's organizational climate to avoid conflict between the elements contained within the organization. Satisfaction with high service arises due to the elements that exist within an organization can function and interact with each other well. But, the satisfaction in regarding the feeling of a person is not constant or always the same. The existence of great flexibility resulted the fact that the school management should always do an analysis of any factors which might affect the quality of academic services given primarily from organizational performance and organizational climate.

\section{CONCLUSION/RECOMENDATION}

1. Organizational climate at SMK Negeri in Palangkaraya is classified in the good category.

2. Administrative performance at SMK Negeri in Palangkaraya is classified in the high category.

3. The quality of academic services at SMK Negeri in Palangkaraya is classified in the high category.

4. Test results indicate that the school organizational climate has a positive effect on students' academic services satisfaction at SMK Negeri 1 and SMK Negeri 2 in Palangkaraya.

5. Based on the results analysis, it was found that the relationship of organizational climate and administrative performance to the academic services satisfaction at SMK Negeri 2 is higher than the SMK Negeri 1. It is due to the condition that SMK Negeri 1 has not been applying quality standards for school services and administrative performance; in which revealed as one of the factors that affect student's academic services satisfaction provided by vocational high schools in Palangkaraya.

6. En masse, the school organizational climate and administrative performance have a significant effect on students' academic 
services satisfaction at SMK Negeri 1 and SMK Negeri 2 in Palangkaraya.

It is recommended to various parties to provide further assessment and make efforts to further improve in (1) the organizational climate by managing the internal physical aspects of school organization, social aspects, and improving the school organization's management system. (2) Increasing the quality of school administration will improve the administration performance, which can be viewed from the physical aspects, responsibilities to the work, and socialization with the surrounding environment. (3) Academic service satisfaction can be increased if both of the above factors are upgraded maximally.

\section{REFERENCES}

Ballantine, Jeanne. H dan Spade, Joan. Z. (2008) Schools and Society: A sociological approach to education. London: Sage Publication.

Burgio, Louis. D, Whitman, Thomas.L dan Reid, Dennis.H. (1983). A Participative Management Approach For Improving Direct-Care Staff Performance In An Institutional Setting. Journal of Applied Behavior Analysis. Vol. 16(1). Pp. 37 53.

Chimombo, Joseph P.G. (2005). Issues in basic education in developing countries: an exploration of policy options for improved delivery. Journal of International Cooperation in Education, Vo. 8, No. 1. Pp. 129 - 152.

Ehren, M.C.M \& Visscher, A.J. (2006). Towards a theory on the impact of school inspections. British Journal of Educational Studies Vol 54, Issue 1 , pp. $51-72$.

Goodson, Ivor \& Hargreaves, Andy. (2006). Educational change over time? The sustainability and nonsustainability of three decades of secondary school change and continuity. SAGE Journal of Educational Administration Quarterly, Vol 2 Issue 1 , pp. $3-41$.
Griffith, James (2004). Relation of principal transformation leadership to school staff job satisfaction, staff turnover and school performance. Journal of Education Administration. Vol. 42(3). Pp. 333-356.

Hanushek, Eric.A, Kain, John. F, Rivkin, Steven.G., and Branch, Gregory. F. (2007). Charter School Quality And parental Decision Making With School Choice. Journal Of Public Economics. Vol 91 (5-6). Pp. 823-848.

Hill, Frances. M . (1995) Managing service quality in higher education; the role of the student as primary consumer. Journal of Quality of assurance in education. Vol. 3 (3). Pp. 10-21.

Jayanthi, Ranjan \& Saani, Khalil. (2007). Application of knowledge management in management education: a conceptual framework. Journal of theoretical \& applied information technology, Vol. 3 Issue 3, pp. $15-25$.

Lacey. C. Hightown. (1970). Grammar: The School as a social System. British Journal of Education Studies. Vol. 19(1). Pp. 99-100.

Leu, Elizabeth. (2005). The role of teachers, schools, and communities in quality education: a review of the literature. AED Global Learning Group, AED Global Education Center: Washington.

Maslowski, R. (2006). A review of inventories for diagnosing school culture. Journal of Educational Administration, Vol. 44 Issue: 1, pp.6-35

Ng, Pak Tee \& Chan, David. (2008). A comparative study of Singapore's school excellence model with Hong Kong's school-based management. International Journal of Educational Management, Vo. 22 Issue 6, pp. 488-505.

Oldfield, Brenda. M. dan Baron, Steve.(2000). Student perceptions of service quality in UK University Business and management faculty. Journal of Quality assurance in education. Vol. 8(2). Pp.8595.

Olorunniwo, Festus, Hsu, Maxwell K. dan Godwin J. Udo, (2006) "Service quality, customer satisfaction, and behavioral intentions in the service factory", Journal of Services Marketing, Vol. 20 Issue: 1 , pp. $59-72$. 